\title{
Temporal changes in atrial EC-coupling during prolonged stimulation with endothelin-1
}

\author{
Martin D. Bootman a , Dagmar Harzheim ${ }^{\text {a }}$, Ioannis Smyrnias ${ }^{\text {a }}$, \\ Stuart J. Conway ${ }^{\mathrm{b}}$, H. Llewelyn Roderick ${ }^{\mathrm{a}, \mathrm{c}, *}$ \\ ${ }^{a}$ Laboratory of Molecular Signalling, The Babraham Institute, Babraham Hall, Babraham, Cambridge CB22 3AT, UK \\ ${ }^{\mathrm{b}}$ Department of Chemistry, School of Chemistry, University of St. Andrews, North Haugh, St. Andrews, Fife KY16 9ST, UK \\ ${ }^{\mathrm{c}}$ Department of Pharmacology, University of Cambridge, Tennis Court Road, Cambridge CB2 1PD, UK
}

Received 1 May 2007; accepted 8 May 2007

Available online 14 June 2007

\begin{abstract}
Endothelin-1 (ET-1) is a potent $\mathrm{G}_{\mathrm{q}}$-coupled agonist with important physiological effects on the heart. In the present study, we characterised the effect of prolonged ET-1 stimulation on $\mathrm{Ca}^{2+}$ signalling within acutely isolated atrial myocytes. ET-1 induced a reproducible and complex sequence of effects, including negative inotropy, positive inotropy and pro-arrhythmic spontaneous $\mathrm{Ca}^{2+}$ transients (SCTs). The negative and positive inotropic effects correlated with the ability of $\mathrm{Ca}^{2+}$ to propagate from the subsarcolemmal sites where EC-coupling initiates into the centre of the atrial cells. We examined the spatial and temporal properties of the SCTs and observed them to range from elementary $\mathrm{Ca}^{2+}$ sparks, flurries of $\mathrm{Ca}^{2+}$ sparks, to $\mathrm{Ca}^{2+}$ waves and action potential-evoked global $\mathrm{Ca}^{2+}$ transients. The positive inotropic effect of ET-1 and its ability to trigger SCTs were mimicked by direct stimulation of $\mathrm{InsP}_{3} \mathrm{Rs}$. An antagonist of $\mathrm{InsP}_{3} \mathrm{Rs}$ prevented the generation of SCTs and partially reduced the positive inotropy evoked by ET-1. Our data suggest that ET-1 engages multiple signal transduction pathways to provoke a plethora of different responses within an atrial myocyte. Some of the actions of ET-1 appear to be due to stimulation of InsP $\mathrm{R}_{3}$.
\end{abstract}

(C) 2007 Elsevier Ltd. All rights reserved.

Keywords: Calcium; Contraction; Atrial; Myocyte; Inositol; Endothelin

\section{Introduction}

Calcium $\left(\mathrm{Ca}^{2+}\right)$ is the key regulator of heart contraction [1]. During each heart beat fluxes of $\mathrm{Ca}^{2+}$ occur across the cardiac myocyte plasma membrane, the sarcolemma, and from the internal $\mathrm{Ca}^{2+}$ store, the sarcoplasmic reticulum (SR). This excitation-contraction coupling (EC-coupling) process is initiated by an action potential that sweeps from the pacemaking region of the heart in the sino-atrial node. When the depolarising action potential reaches the excitable cells within the heart it causes depolarisation of the sarcolemma leading to activation of L-type voltage-operated $\mathrm{Ca}^{2+}$ channels (VOCs) and a

\footnotetext{
* Corresponding author at: Laboratory of Molecular Signalling, The Babraham Institute, Babraham Hall, Babraham, Cambridge CB22 3AT, UK. Tel.: +44 1223496 433; fax: +44 1223496033 .

E-mail address: llewelyn.roderick@bbsrc.ac.uk (H.L. Roderick).
}

consequent influx of $\mathrm{Ca}^{2+}$. The opening of VOCs provides a trigger $\mathrm{Ca}^{2+}$ signal to provoke more substantial $\mathrm{Ca}^{2+}$ release from closely apposed ryanodine receptor (RyR) clusters on the SR, by a process known as $\mathrm{Ca}^{2+}$-induced $\mathrm{Ca}^{2+}$ release (CICR) [2,3]. Activation of RyRs leads to the generation of 'elementary' $\mathrm{Ca}^{2+}$ signals known as a ' $\mathrm{Ca}^{2+}$ sparks'. These microscopic signals essentially reflect the simultaneous activation of a cluster of RyRs by CICR [4-6]. For ventricular cardiomyocytes, the spatial overlap and temporal summation of signals from multiple $\mathrm{Ca}^{2+}$ spark sites underlies the rapid homogenous $\mathrm{Ca}^{2+}$ transients that trigger co-ordinated ventricular myocyte contraction $[5,7,8]$.

EC-coupling in atrial myocytes is substantially different from that in ventricular cells [9]. Atrial cells lack the T-tubule invaginations of the sarcolemma found in ventricular myocytes, and therefore express VOCs only on the sarcolemma surrounding the cells [10]. The distribution of 
RyRs in atrial cells is similar to that in ventricular myocytes, but with the important exception that only a small fraction of the RyRs (the 'junctional RyRs') in the subsarcolemmal region are positioned to respond to the opening of the VOCs $[11,12] . \mathrm{Ca}^{2+}$ signals in atrial myocytes therefore originate around the periphery of the cells and are locally amplified by the junctional RyRs.

Under control conditions, this peripheral $\mathrm{Ca}^{2+}$ signal does not propagate fully, or at all, into the centre of an atrial cell. This means that at the peak of the response, substantial $\mathrm{Ca}^{2+}$ gradients can be observed [12-15]. However, in addition to the junctional RyRs, atrial myocytes have a regular threedimensional lattice of 'non-junctional' RyR clusters spaced $\sim 2 \mu \mathrm{m}$ apart, which pervade the entire cytoplasmic compartment [16]. It could be expected that the subsarcolemmal $\mathrm{Ca}^{2+}$ signal arising from the junctional RyRs would be sensed and amplified by the non-junctional RyRs via CICR. In this way, the trigger $\mathrm{Ca}^{2+}$ signal in the cell periphery could lead to centripetal propagation of a $\mathrm{Ca}^{2+}$ wave and complete engulfment of the cell. However, in the absence of positive inotropic stimulation, the non-junctional RyRs in the centre of atrial myocytes are largely unresponsive. This is due to cellular buffering mechanisms that inhibit inward propagation of the $\mathrm{Ca}^{2+}$ signal [17]. To stimulate contraction, the $\mathrm{Ca}^{2+}$ signal has to overcome the buffers and invade the cell centre where the bulk of the myofilaments exist [9].

The contraction of cardiac myocytes within the heart is regulated by various neurohormonal factors, which can increase or decrease blood pumping. Our work is focussed on understanding the mechanisms by which the potent vasoconstrictive peptide endothelin-1 (ET-1) alters cardiac $\mathrm{Ca}^{2+}$ signalling. One of the functions of ET-1 is to provide short-term inotropic support for a failing heart. However, in addition, ET-1 can lead to arrhythmogenesis and cardiac remodelling [18]. ET-1 concentration has been shown to be increased in cardiac tissues during pathological conditions such as congestive heart failure and myocardial infarction [19]. Furthermore, ET-1 can cause arrhythmias, independent of coronary vasoconstriction, in both normal and diseased hearts [20]. Understanding the mechanism of action of ET-1 is therefore clinically important.

The molecular processes underlying the inotropic and proarrhythmic effects of ET-1 are not entirely clear. Proposed mechanisms include stimulation of $\mathrm{Ca}^{2+}$ release [21,22], enhanced L-type $\mathrm{Ca}^{2+}$ current following activation of protein kinase C (PKC) [23] and sensitization of myofilaments following either PKC- or Rho kinase-mediated phosphorylation [24-26] or alkalinization resulting from increased $\mathrm{Na}^{+} / \mathrm{H}^{+}$ exchange [20].

ET-1 can be transported around the circulatory system following its secretion from vascular endothelial cells. It is also released from endothelial cells within the heart, and also by cardiac myocytes themselves. Whilst it is known that $\mathrm{G}_{\mathrm{q}}$ coupled hormones cause inotropic effects and can mediate changes in gene expression underlying conditions such as hypertrophy, it is not entirely clear what signal transduction pathways mediate the varied actions of such agonists. For endothelin, two receptor isotypes have been cloned (denoted $\mathrm{ET}_{\mathrm{A}}$ and $\mathrm{ET}_{\mathrm{B}}$ ). The predominant cardiac endothelin receptor isotype is $\mathrm{ET}_{\mathrm{A}}$, although the ratio of the two receptor forms varies within the heart $[19,20]$. Both receptor types have been demonstrated to signal via the $G$ protein $G_{q / 11}$ to cause the activation of phospholipase C (PLC). Hydrolysis of phosphatidylinositol-4,5-bisphosphate by PLC on the inner leaflet of the plasma membrane yields two products; inositol1,4,5-trisphosphate $\left(\mathrm{InsP}_{3}\right)$ and diacylglycerol (DAG) [27]. $\mathrm{InsP}_{3}$ is water soluble, diffuses into cells and binds to specific receptors $\left(\mathrm{InsP}_{3} \mathrm{Rs}\right)$ that channel $\mathrm{Ca}^{2+}$ from the lumen of the SR (or endoplasmic reticulum) to the cytosol [28-30]. DAG stays in the plasma membrane, where it can be metabolised further or activate numerous additional effectors such as protein kinase C (PKC) and Ras [31,32].

Numerous studies have demonstrated the expression of Ins $\mathrm{P}_{3} \mathrm{R}$ mRNA and protein in cardiac myocytes from various mammalian species [22,33-36]. Furthermore, InsP ${ }_{3} \mathrm{Rs}$ have been purified from ventricular myocytes, incorporated into lipid bilayers and shown to be functional [37]. Agoniststimulated increases in myocyte $\mathrm{InsP}_{3}$ concentration have been monitored [38], and there are a growing number of studies showing that increased $\mathrm{InsP}_{3}$ levels modulate $\mathrm{Ca}^{2+}$ release from internal stores within cardiac myocytes [39-44]. Despite these data, it is not widely accepted that $\mathrm{InsP}_{3} \mathrm{Rs}$ can make a significant contribution to $\mathrm{Ca}^{2+}$ signalling in the heart. Within the adult mammalian heart, the ratio of InsP $\mathrm{P}_{3} \mathrm{R}: \mathrm{RyR}$ expression is approximately 1:100 [45]. This would suggest that the flux of $\mathrm{Ca}^{2+}$ through $\mathrm{InsP}_{3} \mathrm{Rs}$ could be swamped by the activity of RyRs [46]. However, the concerted opening of $\mathrm{InsP}_{3} \mathrm{Rs}$, or stimulation of regenerative CICR from neighbouring RyRs could cause InsP $\mathrm{P}_{3}$-mediated $\mathrm{Ca}^{2+}$ signals to have a profound effect on cardiac $\mathrm{Ca}^{2+}$ handling. In the present study, we characterised the effects of long-term incubation of atrial myocytes with ET- 1 and the nature of the spontaneous $\mathrm{Ca}^{2+}$ transients (SCTs) that were evoked. In particular, we explored the potential role of $\mathrm{InsP}_{3}$ as an intracellular messenger mediating the actions of ET- 1 .

\section{Materials and methods}

\subsection{Materials}

Collagenase type B was purchased from Worthington Biochemical Corporation. Endothelin-1 was obtained from Calbiochem. Salts for extracellular solutions were purchased form Sigma-Aldrich or $\mathrm{BDH}$. $\mathrm{Ca}^{2+}$-sensitive fluorescent indicators were purchased from Molecular Probes. Rats were obtained from Harlan.

\subsection{Myocyte isolation}

Atrial myocytes were isolated as described previously [12]. In brief, Wistar rats weighing approximately $250 \mathrm{~g}$ 
were anaesthetised in a $\mathrm{CO}_{2}$ chamber and then killed by cervical dislocation. The heart was then dissected from the thorax and positioned on a modified Langendorff apparatus and perfused in a retrograde manner with HEPES buffer solution $\left(\mathrm{NaCl} 135 \mathrm{mM}, \mathrm{KCl} 5 \mathrm{mM}, \mathrm{CaCl}_{2} 1 \mathrm{mM}\right.$, HEPES $10 \mathrm{mM}$, glucose $10 \mathrm{mM}$ and $\left.\mathrm{MgCl}_{2} 0.4 \mathrm{mM}, \mathrm{pH} 7.35\right)$ at $37^{\circ} \mathrm{C}$. This was followed by perfusion with a low $\mathrm{Ca}^{2+}$ buffer solution ( $\mathrm{NaCl} 120 \mathrm{mM}$, $\mathrm{KCl} 5 \mathrm{mM}, \mathrm{CaCl}_{2} 80 \mu \mathrm{M}$, HEPES $10 \mathrm{mM}$, taurine $20 \mathrm{mM}$, glucose $20 \mathrm{mM}, \mathrm{MgSO}_{4} 5 \mathrm{mM}$, NTA $5.5 \mathrm{mM}$, and pyruvate $5 \mathrm{mM}$, pH 6.96) for $3.5 \mathrm{~min}$. Following the low $\mathrm{Ca}^{2+}$ solution, an enzyme buffer solution $(\mathrm{NaCl}$ $120 \mathrm{mM}, \mathrm{KCl} 5 \mathrm{mM}, \mathrm{CaCl}_{2} 35 \mu \mathrm{M}$, HEPES $10 \mathrm{mM}$, taurine $20 \mathrm{mM}$, glucose $20 \mathrm{mM}, \mathrm{MgSO}_{4} 5 \mathrm{mM}$ and pyruvate $5 \mathrm{mM}$, $\mathrm{pH}$ 7.4) was recirculated through the apparatus for $10 \mathrm{~min}$. This solution also contained $118 \mathrm{Iu} \mathrm{ml}^{-1}$ type B collagenase (Worthington). Following dissociation of the myocytes, they were allowed to settle, and $\mathrm{Ca}^{2+}$ was reintroduced in an incremental manner to prevent intracellular $\mathrm{Ca}^{2+}$ overload and hypercontracture. The myocytes were kept at room temperature until ready for use. Only myocytes with no signs of deterioration and that had no spontaneous activity at rest were used for experiments. The myocytes were settled on polyL-lysine-coated coverslips for $45 \mathrm{~min}$ before loading with a fluorescent $\mathrm{Ca}^{2+}$ indicator. All experiments were performed in accordance with the guidelines from the code of practice for humane killing under Schedule 1 of the Animals (Scientific Procedures) Act 1986.

\subsection{Photometry and confocal imaging}

For photometry experiments, cells were loaded with indo1 by incubation with the acetoxymethyl ester form of the fluorophore ( $3 \mu \mathrm{M}$ for $30 \mathrm{~min})$. The cells were then washed in fresh buffer and left for $30 \mathrm{~min}$ before use to allow complete de-esterification. For laser scanning confocal microscopy experiments, cells were loaded with fluo-3 using a similar procedure to that for indo-1, except that the myocytes were incubated with $2 \mu \mathrm{M}$ fluo-3 acetoxymethyl ester for $20 \mathrm{~min}$.

For the photometry recordings, coverslips bearing indo1-loaded myocytes were placed on the stage of an inverted microscope (Nikon TE 200) and superfused with HEPES buffer solution containing $1 \mathrm{mM} \mathrm{CaCl}_{2}$. The cells were stimulated $(40 \mathrm{~V}, 2 \mathrm{~ms}$ duration) via a pair of platinum field electrodes placed equidistant from the cell (distance between electrodes was $1 \mathrm{~cm}$ ). The pacing frequency was $0.33 \mathrm{~Hz}$.

Indo-1 was excited using $360 \mathrm{~nm}$ light, and the fluorescence emission at 405 and $490 \mathrm{~nm}$ was sampled using two independent photomultiplier detectors every $10 \mathrm{~ms}$. The photomultiplier signals were digitised using an analogue to digital converter controlled by PhoCal Pro (PerkinElmer, UK). The background fluorescence at 405 and $490 \mathrm{~nm}$ emission was determined from fields of view without cells, and this was automatically subtracted from the subsequent experimental records by the software. The cells were paced continually throughout an experiment. However, to reduce bleaching of the indicator, indo-1 fluorescence was sam- pled discontinuously (30 s illumination and recording period followed by $90 \mathrm{~s}$ without illumination). The fluorescence emission ratio $(405 \mathrm{~nm} / 490 \mathrm{~nm})$ increases as $\mathrm{Ca}^{2+}$ is elevated. The fluorescence ratio was converted into $\mathrm{Ca}^{2+}$ concentration using a calibration procedure described previously [47].

For the confocal recordings, coverslips bearing fluo-3loaded myocytes were placed on the stage of an inverted microscope (Nikon TE 300) and superfused with HEPES buffer solution containing $1 \mathrm{mM} \mathrm{CaCl}_{2}$. The pacing apparatus and conditions were the same as those described above for photometry. The real-time confocal images were obtained using a NORAN Oz (Middleton, USA) and digitised using Noran's Intervision software running on a Silicon Graphics computer. Two-dimensional confocal images $(512 \times 115$ pixels; confocal slit aperture $25 \mu \mathrm{m}$ ) were acquired at $120 \mathrm{~Hz}$. Laser excitation of fluo-3 was applied in $10 \mathrm{~s}$ bursts at pre-set times over a $12.5 \mathrm{~min}$ period. The gain and brightness controls were set to ensure positive background pixel intensities at the start of the experiment, and also to allow the subsequent fluorescence changes to be acquired within the 8-bit range of the Oz.

Superfusion of cells was accomplished using a gravitydriven flow of solution over the top of the cells. All experiments were performed at room temperature (20-22 ${ }^{\circ} \mathrm{C}$ ), since cell viability and dye loading is prolonged at this temperature. Prior to starting experiments, all cells were paced for a brief period to establish a steady-state $\mathrm{Ca}^{2+}$ response. During this period, there was a 'positive staircase' indicative of $\mathrm{Ca}^{2+}$ loading. Generally, it took between 10 and 20 depolarisations to reach equilibrium.

\subsection{Contraction measurements}

For contraction measurements, myocytes were paced in a pacing chamber $(0.33 \mathrm{~Hz}, 80 \mathrm{~V})$ on the stage of an inverted microscope (Olympus IX71) and superfused with HEPES buffer solutions containing $1 \mathrm{mM} \mathrm{CaCl}_{2}$. Contraction (cell shortening) was measured optically with a video edge detector and recorded using Felix software (Photon Technology International). The cells were paced continuously but the contraction was sampled discontinuously (30 s recording period, $30 \mathrm{~s}$ pause). The amplitude of contraction was calculated as the difference between the maximum in cell length at the end of the diastolic phase and the minimum in cell length during each pacing cycle. The amplitude of contraction was averaged for each $30 \mathrm{~s}$ recording interval.

\section{Results}

\subsection{Timecourse of the response to ET-1}

Prolonged superfusion of atrial myocytes with ET-1 $(100 \mathrm{nM})$ induced a complex sequence of changes in the amplitude of electrically evoked whole-cell $\mathrm{Ca}^{2+}$ transients. This is evident from Fig. 1A, which shows the peak sys- 
(A)
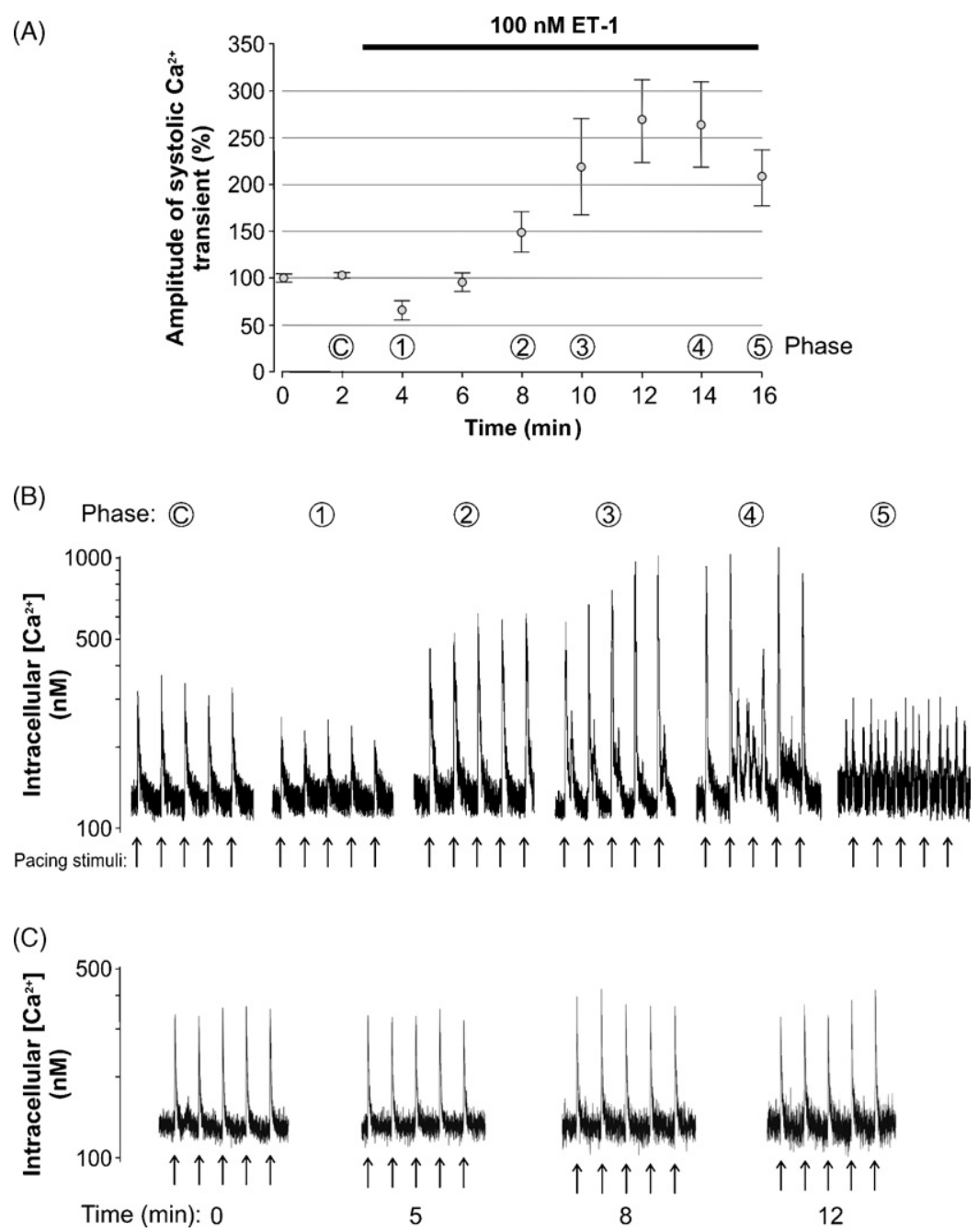

Fig. 1. Effect of ET-1 on $\mathrm{Ca}^{2+}$ signalling in atrial myocytes. Panel A depicts the effect of continuous stimulation of atrial myocytes with $100 \mathrm{nM}$ ET-1 on systolic $\mathrm{Ca}^{2+}$ signals. The data points show the normalised systolic $\mathrm{Ca}^{2+}$ transient amplitude monitored using photometry (data capture rate $2 \mathrm{~ms}$ ). Data were obtained by averaging the peak systolic signal over $30 \mathrm{~s}$ periods, and sampling at $90 \mathrm{~s}$ intervals. The symbols indicate mean \pm S.E.M. $(n=5)$. The photometry traces in panels B and C show representative indo-1 signals from single electrically paced atrial myocytes. For panel B, the myocyte was superfused with $100 \mathrm{nM}$ ET-1 after the steady-state pacing condition had been established. The response depicted in panel $\mathrm{C}$ was obtained from an atrial myocyte that was superfused with control solution only. The traces in B and $\mathrm{C}$ are typical of at least 10 cells from 3 different cell preparations.

tolic $\mathrm{Ca}^{2+}$ signal during a 14 min application of ET-1. Before application of the hormone, the cells were paced until they had reached a steady-state condition (denoted as phase C; control), in which the amplitude of the pacing-evoked $\mathrm{Ca}^{2+}$ transients was consistent. Rapidly after commencing superfusion with ET-1, the amplitude of the $\mathrm{Ca}^{2+}$ transients declined significantly (phase 1; negative inotropy). On average, the peak amplitude declined to $70.0 \pm 10.1 \%$. This was followed by a gradual recovery of the systolic $\mathrm{Ca}^{2+}$ transient amplitude (phases 2 and 3; positive inotropy), until the signal reached maximum (phase 4; peak amplitude was $265.3 \pm 61.5 \%$ of control). The positive inotropic state persisted in some (40\%), but not all cells. In those cells, where positive inotropy was not maintained, the amplitude of the pacing-evoked $\mathrm{Ca}^{2+}$ transients rapidly declined (phase 5).

The reason for the reduction of the systolic $\mathrm{Ca}^{2+}$ transients in phase 5 was the incidence of spontaneous $\mathrm{Ca}^{2+}$ tran- sients (SCTs) during the normally quiescent diastolic periods. The SCTs usually occurred concomitantly with the positive inotropic phases (2, 3 or 4), and progressively increased in frequency. High frequency SCTs can reduce systolic $\mathrm{Ca}^{2+}$ responses since they cause unloading of the $\mathrm{SR} \mathrm{Ca}^{2+}$ pool [48]. Indeed, in phase 5 the SCTs were often so frequent that the electrical stimulation no longer evoked a response. Similar effects of ET-1 were observed in cells studied at room temperature or $37^{\circ} \mathrm{C}$, with the difference that the transition from negative to positive inotropic effect was achieved more rapidly at the higher temperature. The frequency of SCTs was slightly greater at $37^{\circ} \mathrm{C}$.

The typical response of a single atrial myocyte to continuous ET-1 stimulation is depicted in Fig. 1B. The pattern of negative inotropy, followed by positive inotropy was evident, as was the progressive increase in SCTs. In phase 4, the cell could be seen to miss a triggered systole. This was due to the 
(A)

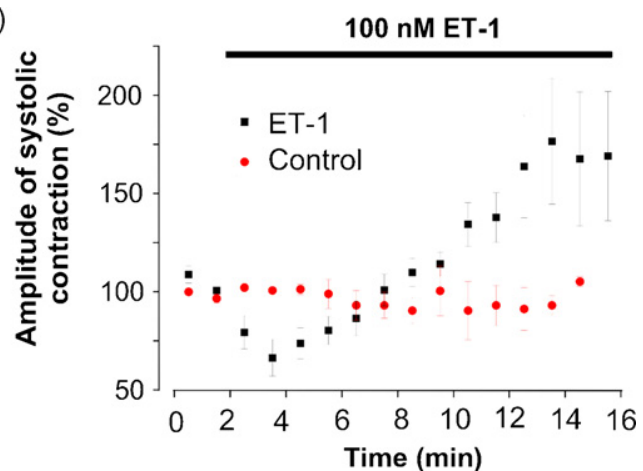

(B)

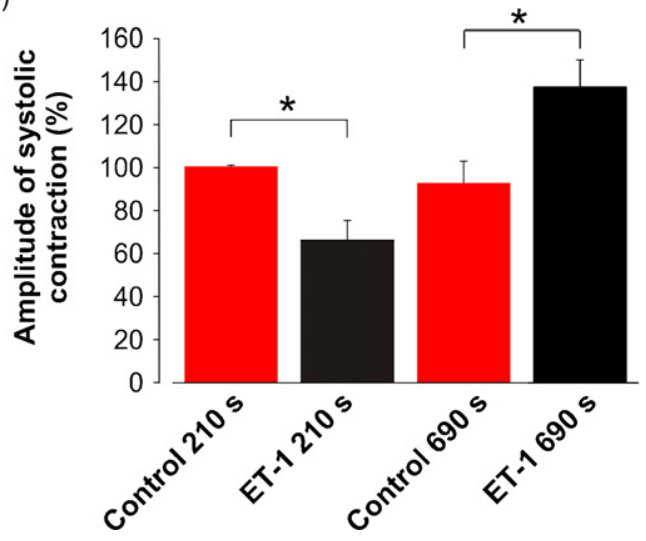

Fig. 2. Effect of ET-1 on contraction in atrial myocytes. Panel A illustrates the effect of continuous stimulation of atrial myocytes with ET-1 (100 nM; black symbols) or control buffer (control; red symbols) on cellular contraction. The data points show the normalised systolic contraction sampled every $30 \mathrm{~s}$. The symbols indicate mean \pm S.E.M. $(n=5)$. Panel B compares the relative amplitude of contraction of control cells with ET-1-stimulated cells during the negative inotropic $(210 \mathrm{~s})$ and positive inotropic $(690 \mathrm{~s})$ phases. The columns represent mean \pm S.E.M. $(n=5) . * p<0.05$, which was calculated using Student's $t$-test.

presence of multiple SCTs that made the myocyte electrically inert. A few minutes later in phase 5, the cell was displaying random arrhythmic $\mathrm{Ca}^{2+}$ signals that had little temporal correlation to the applied pacing regime. In the absence of ET-1, cells could be paced with no change in the characteristics of the evoked $\mathrm{Ca}^{2+}$ signals (Fig. 1C).

The pattern of systolic $\mathrm{Ca}^{2+}$ response depicted in Fig. 1A was mirrored by myocyte contraction. Whereas control cells maintained consistent twitch amplitudes for the duration of the electrical pacing, ET-1 caused both negative and positive inotropy (Fig. 2A). The ET-1-induced changes in contraction occurred over the same time course as the corresponding $\mathrm{Ca}^{2+}$ changes (Fig. 1). The amplitudes of contraction during the negative and positive inotropic phases were significantly different from that in control cells (Fig. 2B).

To further examine the relationship between changes in $\mathrm{Ca}^{2+}$ transient amplitude and magnitude of contraction, we investigated the spatial profile of $\mathrm{Ca}^{2+}$ signals during ET-1 stimulation using confocal microscopy. The three montages of images in Fig. 3Ai-iii depicts the same fluo-3-loaded atrial myocyte that was imaged before (control; left-hand montage) or after ET-1 superfusion (middle and right-hand montage). The cell images were obtained just as the cell was being electrically stimulated (stimulation is indicated by the horizontal arrow). In the control condition, it was evident that the $\mathrm{Ca}^{2+}$ signal arose initially in the subsarcolemmal region of the cell, and then spread centripetally inwards. At the peak of the response (Fig. 3Ai at $32 \mathrm{~ms}$ post-stimulation), the $\mathrm{Ca}^{2+}$ signal had propagated towards the centre of the myocyte, but had not completely engulfed the cell. During the negative inotropic phase, following application of ET-1 for $3 \mathrm{~min}$, both the subsarcolemmal and central $\mathrm{Ca}^{2+}$ responses declined (Fig. 3Aii). In contrast, with prolonged application of ET-1 so that the cell could reach a positive inotropic state, the subsarcolemmal $\mathrm{Ca}^{2+}$ response was enhanced and the centripetal propagation of the $\mathrm{Ca}^{2+}$ signal spread completely throughout the cell. In addition to a larger $\mathrm{Ca}^{2+}$ signal during the positive inotropic phase, the cell was observed to have a substantially enhanced contraction (Fig. 3Aiii). The relative $\mathrm{Ca}^{2+}$ changes in the subsarcolemmal and central regions of the myocyte are depicted in Fig. 3B (note that for clarity only portions of the response that were devoid of SCTs are shown). It is evident that the subsarcolemmal region attained a higher peak $\mathrm{Ca}^{2+}$ response than the central region in both the control and negative inotropic phases. However, during the positive inotropic phase, the amplitudes of the $\mathrm{Ca}^{2+}$ signal in the subsarcolemmal and central regions were indistinguishable.

The centripetal propagation of the $\mathrm{Ca}^{2+}$ signal allowed it to reach the nucleus of the myocytes, which is generally located centrally in atrial cells. In the control situation, the fold change in fluo-3 emission was similar in the nucleus and surrounding cytoplasm (Fig. 3Bi). During the negative inotropic phase, when the centripetal propagation of the $\mathrm{Ca}^{2+}$ signal was weakest, the nucleus appeared to have a lesser fold change in fluo-3 fluorescence emission (Fig. 3Bii). However, the most striking effect of ET-1 on nuclear $\mathrm{Ca}^{2+}$ levels was observed during the positive inotropic phase (Fig. 3Biii), in which the fold change in fluo-3 emission was as great as that in the subsarcolemmal and cytoplasmic regions. In addition, there was an additional component to the nuclear $\mathrm{Ca}^{2+}$ response that distinguished it from the signals in the remainder of the cell. Whereas, the fluo-3 signal from the subsarcolemmal and central regions rapidly peaked and then decayed almost simultaneously, the nucleus displayed an extra surge of $\mathrm{Ca}^{2+}$ (see green trace in Fig. 3Biii). The fact that nuclear $\mathrm{Ca}^{2+}$ increased whilst the cytoplasmic and subsarcolemmal regions were decreasing suggests that the nucleus can produce autonomous signals. It is evident from the image montages in Fig. 3Aiii that the nucleus was initially isolated from the $\mathrm{Ca}^{2+}$ change in the surrounding cytoplasm until $32 \mathrm{~ms}$ after stimulation. At that point $\mathrm{Ca}^{2+}$ invaded the nucleus and triggered the secondary $\mathrm{Ca}^{2+}$ increase perhaps via a CICR mechanism. In addition, as has been demonstrated in other cell types [49], the nuclear $\mathrm{Ca}^{2+}$ rise recovered more slowly than in the rest of the myocyte. 
(A)

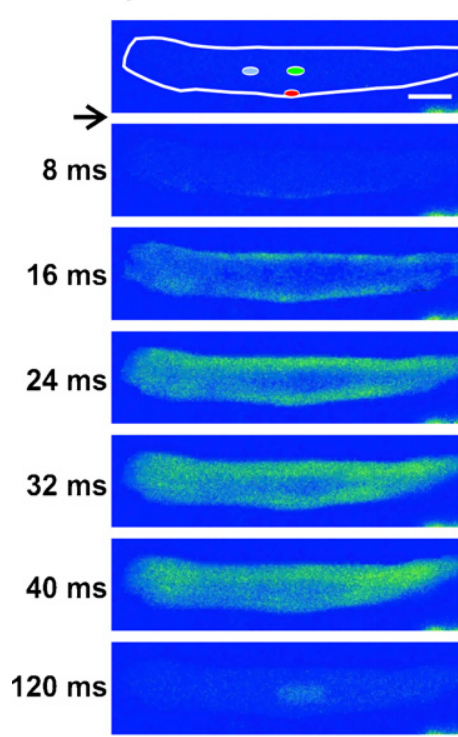

Control

(B)

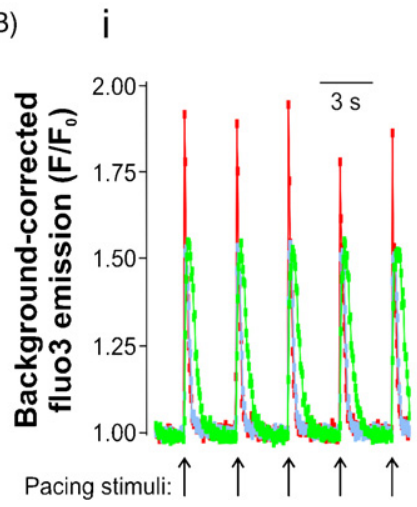

ii
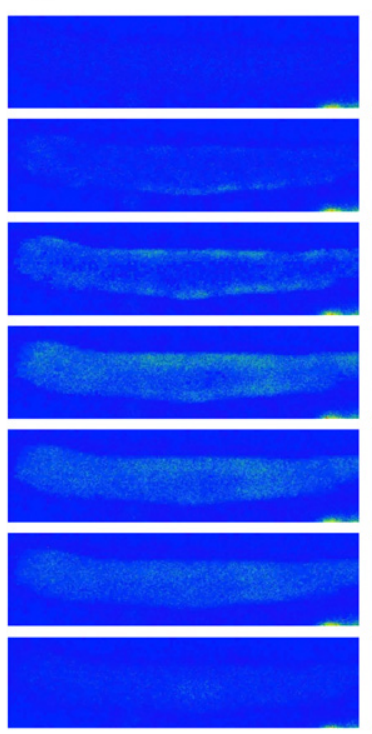

+100 nM ET-1

for 3 minutes

(negative inotropy)

ii

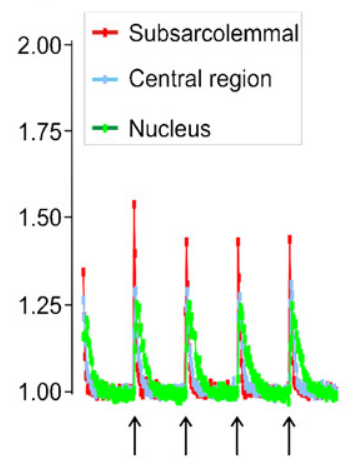

iii
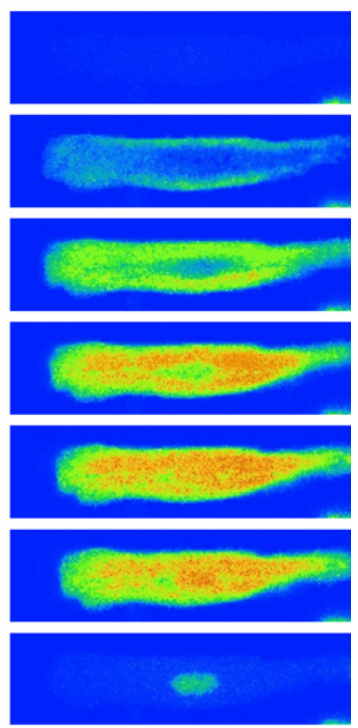

+100nM ET-1

for 10 minutes

(positive inotropy)

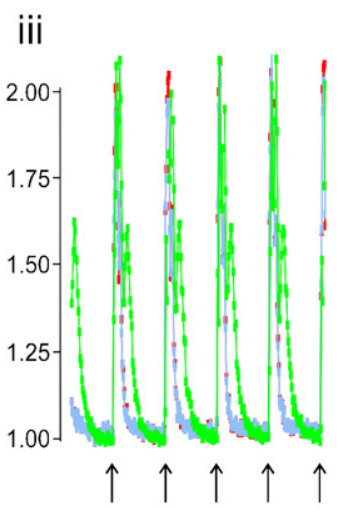

Fig. 3. Spatial and temporal properties of $\mathrm{Ca}^{2+}$ transients in ET-1-stimulated cells. The montages of confocal images in panel A were obtained from a single electrically paced fluo-3-loaded atrial myocyte either before (control; Ai) or after (Aii and iii) superfusion with ET-1 (100 nM). The outline of the cell is shown in the top image in Ai. The cell was electrically stimulated at the time point indicated by the horizontal arrow. The subsequent frames were captured at $8 \mathrm{~ms}$ intervals following depolarisation, except for the bottom images, which were captured at $120 \mathrm{~ms}$ post-stimulation to emphasise the long-lasting nuclear Ca ${ }^{2+}$ signal. Panel B shows the temporal $\mathrm{Ca}^{2+}$ changes within the myocyte depicted in panel A. The fluo- 3 fluorescence emission was monitored in the regions indicated by coloured circles in top image of panel Ai. The fluo- 3 signal in those cellular regions is indicated by the correspondingly coloured traces in Bi-iii. The white scale bar in A represents $10 \mu \mathrm{m}$.

\subsection{The spontaneous $\mathrm{Ca}^{2+}$ transients (SCTs) stimulated} by ET-1 were $\mathrm{Ca}^{2+}$ sparks, flurries of $\mathrm{Ca}^{2+}$ sparks, $\mathrm{Ca}^{2+}$ waves and action potential-evoked global $\mathrm{Ca}^{2+}$

\section{transients}

The incidence of SCTs correlated with the development of positive inotropy in the ET-1-stimulated atrial myocytes (Fig. 4A). Very few SCTs were recorded in control cells paced in the absence of ET-1. It was evident that ET-1 provoked the occurrence of three different types of SCT during diastole. $\mathrm{Ca}^{2+}$ sparks were obvious in confocal recordings as spatially restricted events ( $\leq 5 \mu \mathrm{m}$ in diameter) with a rapid appearance and decay (lifetime $\leq 150 \mathrm{~ms}$ ). The incidence of $\mathrm{Ca}^{2+}$ sparks grew progressively with the duration of ET-1 stimulation. Both the number of $\mathrm{Ca}^{2+}$ spark sites and the rate of firing of those sites increased (Fig. 4B). Analysis of the positions of the spontaneous $\mathrm{Ca}^{2+}$ spark sites revealed that they predominantly occurred in the subsarcolemmal region of atrial myocytes. This is illustrated in Fig. 4C, which maps the positions of $\mathrm{Ca}^{2+}$ spark sites within an individual myocyte. The progressive activity of the $\mathrm{Ca}^{2+}$ spark sites in this cell is shown quantitatively in Fig. 4D. The amplitude of the $\mathrm{Ca}^{2+}$ sparks did not alter during ET-1 application (Fig. 4E).

Although $\mathrm{Ca}^{2+}$ sparks were often observed as temporallyand spatially discrete events during ET-1 stimulation, they also triggered more substantial $\mathrm{Ca}^{2+}$ signals, as exemplified 
(A)

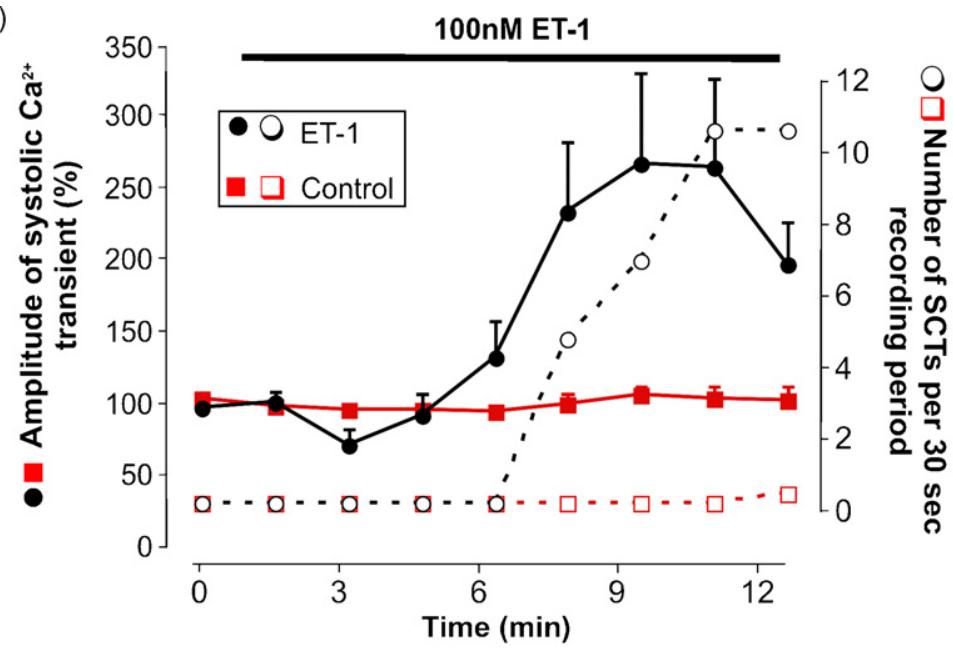

(B)

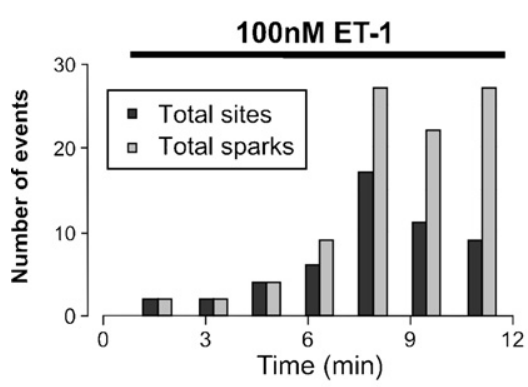

(D)

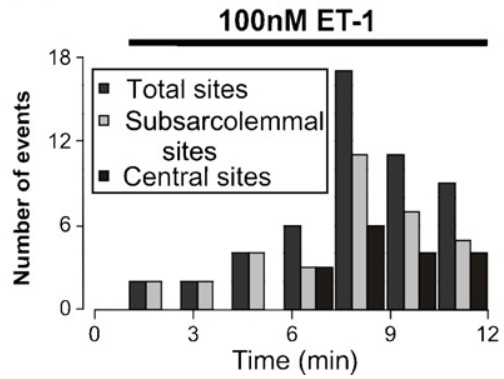

(C)

- Subsarcolemmal spark site

- Central spark site

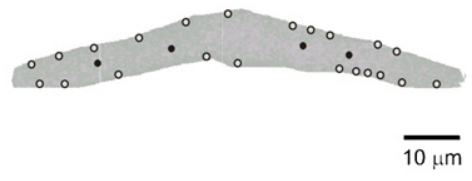

(E)

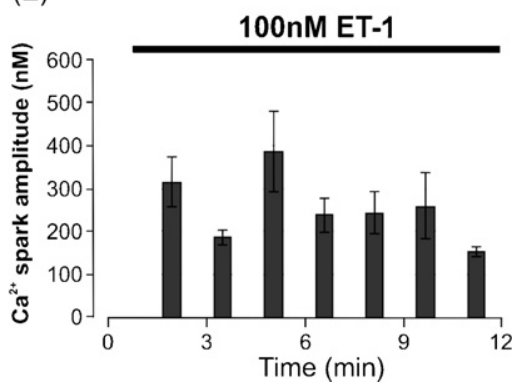

Fig. 4. Concurrent development of positive inotropy and SCTs. Panel A illustrates the temporal coincidence of positive inotropy and SCTs in atrial myocytes. The symbols indicate mean \pm S.E.M. $(n=5)$. The SCT frequency was calculated by counting the number of SCTs apparent in the photometry traces during the $30 \mathrm{~s}$ intervals when systolic $\mathrm{Ca}^{2+}$ was monitored. The black lines and symbols depict the responses of ET-1-stimulated cells. Whereas, the red lines and symbols relate to control cells superfused with extracellular buffer alone. Panel B illustrates the spatial and temporal properties of spontaneous diastolic $\mathrm{Ca}^{2+}$ sparks. The data in panels B-E were obtained from a single atrial myocyte, and are typical of similar observations made in four other cells. The data in panel E represent mean \pm S.E.M. of the $\mathrm{Ca}^{2+}$ sparks observed in $30 \mathrm{~s}$ confocal recording periods.

in Fig. 5. Panels 5A and B illustrate whole-cell $\mathrm{Ca}^{2+}$ signals recorded from a single atrial myocyte that had been stimulated with ET-1 for $10 \mathrm{~min}$. As described earlier, under this condition the cell was displaying positive inotropy and SCTs. The $\mathrm{Ca}^{2+}$ signals evoked by electrical pacing are indicated by the arrows, whereas the SCTs are marked with arrowheads. It is evident that the SCTs had different amplitudes. Fig. 5C-F depicts the temporal and spatial profiles of the two SCTs marked with red arrowheads. One of these events was essentially a flurry of $\mathrm{Ca}^{2+}$ sparks that appeared spon- taneously and then rapidly declined. The globally averaged $\mathrm{Ca}^{2+}$ response of this SCT is shown on an expanded timescale in Fig. 5C (black trace) with a preceding pacing-evoked $\mathrm{Ca}^{2+}$ transient. Superimposed on the photometry trace is a record of the incidence of $\mathrm{Ca}^{2+}$ sparks during the SCT (orange trace in Fig. 5C). Although a single $\mathrm{Ca}^{2+}$ spark is not sufficient to significantly affect the globally averaged $\mathrm{Ca}^{2+}$ concentration within a myocyte, the flurry of $\mathrm{Ca}^{2+}$ sparks was able to cause a substantial deviation of diastolic $\mathrm{Ca}^{2+}$. The SCT declined because the $\mathrm{Ca}^{2+}$ spark activity did not persist. The spatial 
(A)

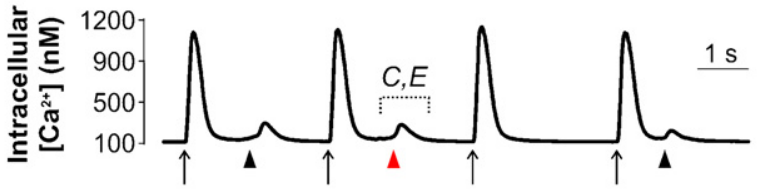

(B)

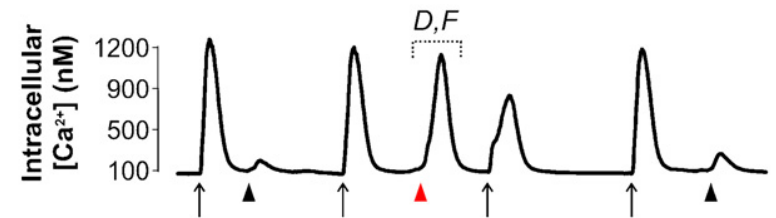

(C)

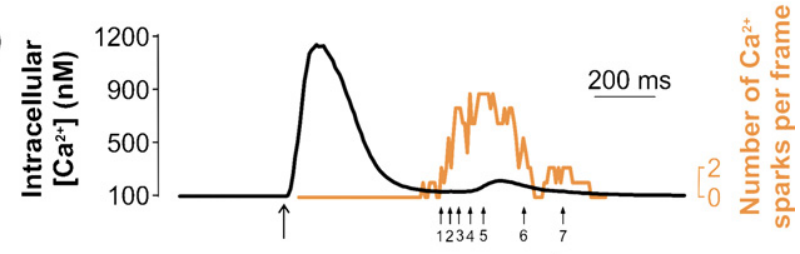

(D)

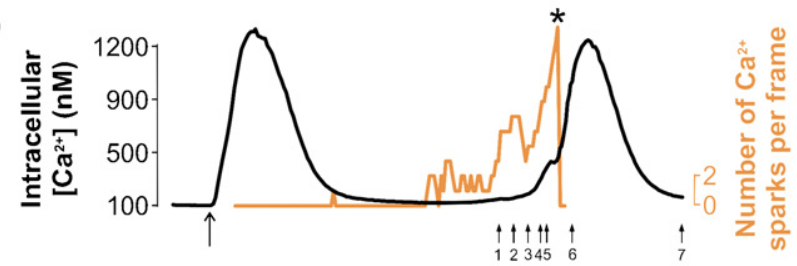

(E)

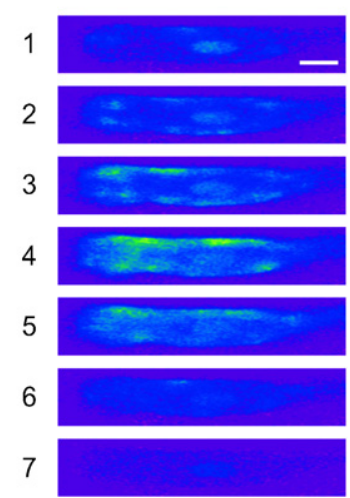

(F)

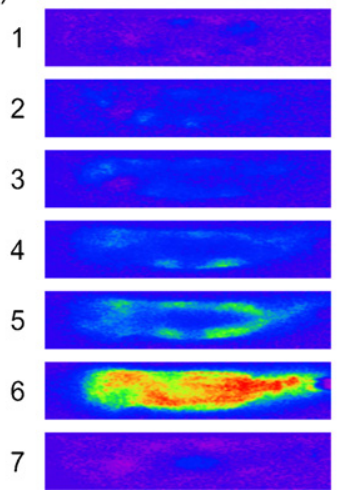

Fig. 5. Transition from flurries of $\mathrm{Ca}^{2+}$ sparks to action potentials in an ET1-stimulated atrial myocyte. The traces in panels A and B depict whole-cell averaged $\mathrm{Ca}^{2+}$ signals within a single atrial myocyte. The cell was electrically paced at the times shown by vertical arrows. Spontaneous diastolic $\mathrm{Ca}^{2+}$ transients of different amplitudes are evident in the traces. The two SCTs indicated by red arrowheads are shown on an expanded timescale by the black traces in panels C and D. Superimposed on the whole-cell averaged $\mathrm{Ca}^{2+}$ signals is the incidence of isolated $\mathrm{Ca}^{2+}$ sparks (orange traces). The numbered arrows beneath the orange traces indicate the times at which the cell images in panels $\mathrm{E}$ and $\mathrm{F}$ were captured. The white scale bar in $\mathrm{E}$ represents $8 \mu \mathrm{m}$.

pattern of the $\mathrm{Ca}^{2+}$ increase during the SCT is depicted in Fig. 5E. The $\mathrm{Ca}^{2+}$ sparks are particularly evident around the subsarcolemmal region of the cell.

The second, larger, SCT showed a markedly different type of response. The temporal profile of that SCT is shown in Fig. 5D (black trace). In that example, the SCT had the same amplitude as the prior pacing-evoked $\mathrm{Ca}^{2+}$ transient, although it had a slower initial rising phase. The plot of $\mathrm{Ca}^{2+}$ spark occurrence (orange trace in Fig. 5D) is overlaid on the $\mathrm{Ca}^{2+}$ recording. It is evident that there was a progressive increase in $\mathrm{Ca}^{2+}$ spark frequency, which was coincident with a gradual rise in diastolic $\mathrm{Ca}^{2+}$. At the point marked with an asterisk (*), the number of obvious discrete $\mathrm{Ca}^{2+}$ sparks declined to zero. The reason for the decline in apparent $\mathrm{Ca}^{2+}$ sparks was the rapid transition to a global $\mathrm{Ca}^{2+}$ signal. At that point, individual $\mathrm{Ca}^{2+}$ sparks could no longer be identified. The sudden upstroke of the $\mathrm{Ca}^{2+}$ transient was due to the triggering of an action potential by the preceding $\mathrm{Ca}^{2+}$ sparks $[21,50]$. The spatial pattern of the $\mathrm{Ca}^{2+}$ response for the larger SCT is illustrated in Fig. 5F. Initially, the larger SCT develops in the same manner as described previously for the smaller SCT (Fig. 5E), in that there is a flurry of subsarcolemmal $\mathrm{Ca}^{2+}$ sparks. However, in the case of the larger SCT, the $\mathrm{Ca}^{2+}$ spark activity does not simply decline, and instead triggers a large global $\mathrm{Ca}^{2+}$ change (panel 6 in Fig. 5F).

Individual $\mathrm{Ca}^{2+}$ sparks, flurries of $\mathrm{Ca}^{2+}$ sparks and $\mathrm{Ca}^{2+}$ spark-triggered action potentials were the most common forms of SCT observed within the ET-1-stimulated atrial myocytes. In addition, we also observed $\mathrm{Ca}^{2+}$ waves that traversed the whole, or a portion, of a cell. $\mathrm{Ca}^{2+}$ waves were particularly evident with prolonged ET-1 stimulation $(n=8)$. An example of a $\mathrm{Ca}^{2+}$ wave is presented in Fig. 6A. As shown in the montage of images, the $\mathrm{Ca}^{2+}$ wave initiated in the periphery of the cell, and spiralled around the nuclear boundary and engulfed the nucleus. As with the majority of $\mathrm{Ca}^{2+}$ waves, this event appeared to be triggered by preceding subsarcolemmal $\mathrm{Ca}^{2+}$ spark activity. The amplitudes of $\mathrm{Ca}^{2+}$ waves were intermediate between flurries of $\mathrm{Ca}^{2+}$ sparks and action potentials. This is evident in Fig. 6B, which shows the globally averaged $\mathrm{Ca}^{2+}$ signal from the cell illustrated in Fig. 6A during the time when $\mathrm{Ca}^{2+}$ waves were observed. The montage of images in Fig. 6A relate to the $\mathrm{Ca}^{2+}$ wave identified by an asterisk (*) in Fig. 6B.

\subsection{Ins $P_{3}$ underlies the arrhythmic effect of ET-1 in atrial myocytes}

We, and others, have demonstrated the expression of functional Ins $\mathrm{P}_{3} \mathrm{Rs}$ in adult atrial myocytes [22,33]. Ins $\mathrm{P}_{3} \mathrm{Rs}$ could provide a parallel $\mathrm{Ca}^{2+}$ release pathway to act in concert with the RyRs that underlie EC-coupling. We therefore sought to determine whether they played a role in any of the responses induced by prolonged ET-1 stimulation. To directly activate $\mathrm{InsP}_{3} \mathrm{Rs}$ a membrane-permeant $\mathrm{InsP}_{3}$ ester was used. This compound has been employed by our lab and several others [21,51-57], and all its effects are consistent with a sole action on InsP $\mathrm{P}_{3} \mathrm{Rs}$.

Similar to ET-1, continuous stimulation of atrial myocytes with $\mathrm{InsP}_{3}$ ester provoked a progressive increase in the amplitude of systolic $\mathrm{Ca}^{2+}$ transients and the occurrence of SCTs (Fig. 7A). However, the effect of InsP $\mathrm{P}_{3}$ ester was different from that of ET-1 in a couple of respects. Firstly, there was no negative inotropy observed in $\mathrm{InsP}_{3}$ ester-treated cells. Also, the $\mathrm{InsP}_{3}$ ester-evoked positive inotropy was not as profound 
(A)

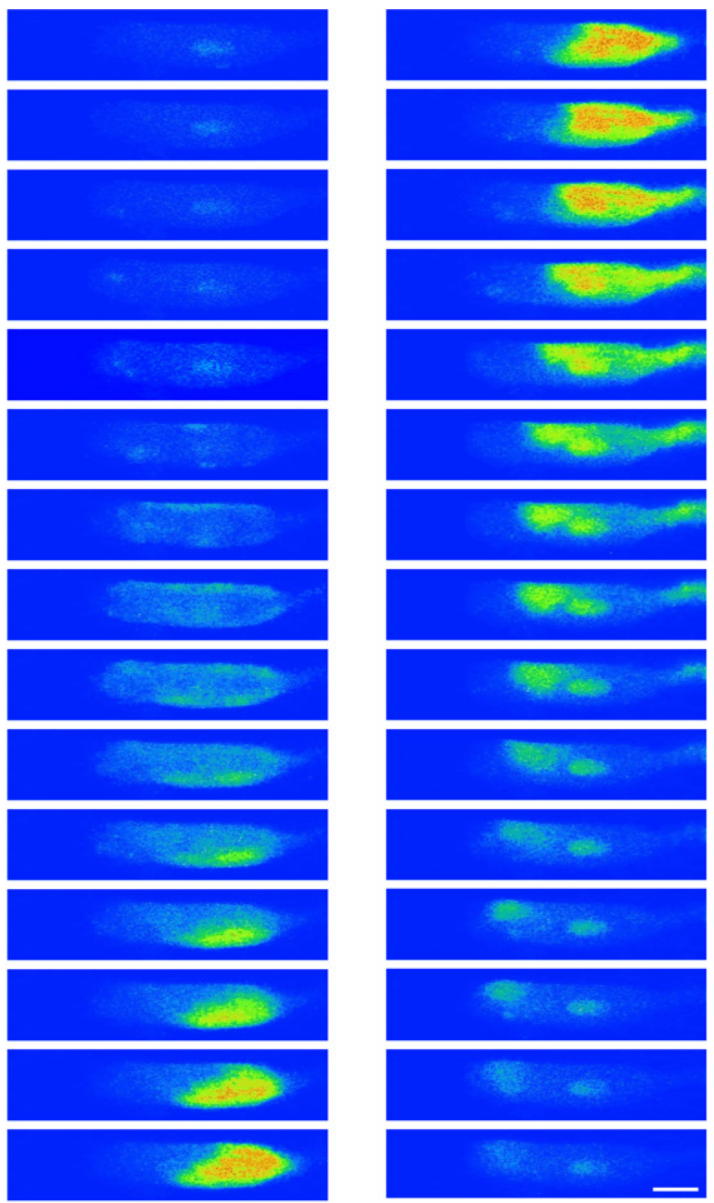

(B) $\quad$ Flurry of $\mathrm{Ca}^{2+}$ sparks

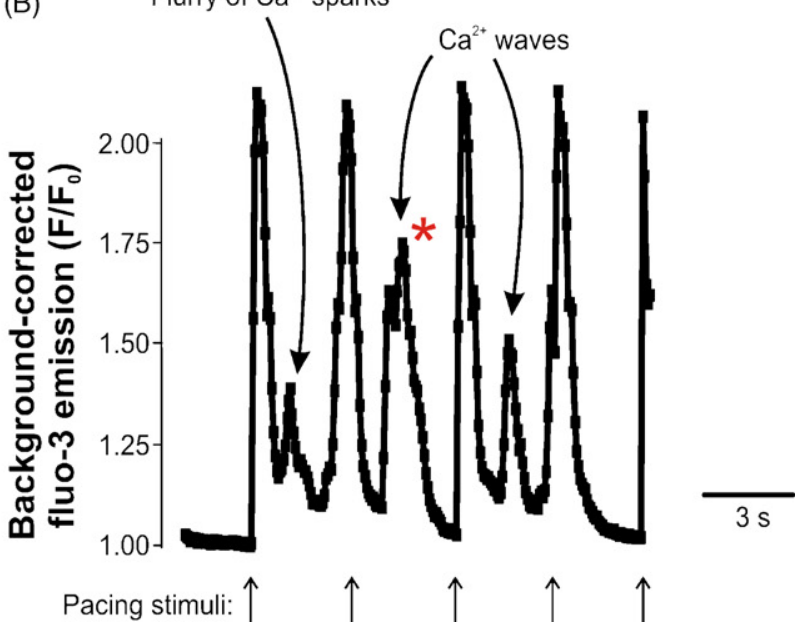

Fig. 6. Transition from flurries of $\mathrm{Ca}^{2+}$ sparks to $\mathrm{Ca}^{2+}$ waves in an ET1 -stimulated atrial myocyte. The montage of images in panel A illustrates the onset of a $\mathrm{Ca}^{2+}$ wave from preceding $\mathrm{Ca}^{2+}$ spark activity. The individual frames were captured sequentially at $8 \mathrm{~ms}$ intervals during the diastolic period. Panel $\mathrm{B}$ depicts the whole-cell averaged $\mathrm{Ca}^{2+}$ signals occurring in the cell shown in panel $\mathrm{A}$ at the time when the $\mathrm{Ca}^{2+}$ wave was recorded. The asterisk $(*)$ in panel $\mathrm{B}$ indicates the actual $\mathrm{Ca}^{2+}$ wave that is represented in panel A. and typically took longer to develop compared to the effect of ET-1. The photometry traces in Fig. 7B illustrate the effect of continuous $\mathrm{InsP}_{3}$ ester stimulation on a single atrial myocyte. The positive inotropic increase in systolic $\mathrm{Ca}^{2+}$ response is evident, as is the activation of SCTs. Furthermore, just like ET-1, the InsP $\mathrm{P}_{3}$ ester had the capacity to drive the cells into a condition in which they could no longer be electrically paced.

These data suggest that $\mathrm{InsP}_{3}$ could mediate the positive inotropic and arrhythmic effects of ET-1. To examine this, we used the membrane-permeant $\operatorname{InsP}_{3} \mathrm{R}$ antagonist 2aminoethoxydiphenyl borate (2-APB) [53]. When applied on its own at a concentration of $2 \mu \mathrm{M}, 2-\mathrm{APB}$ had no effect on pacing-evoked $\mathrm{Ca}^{2+}$ transients (Fig. 7C). However, 2-APB had a marked consequence for the response of atrial myocytes to ET-1 (compare Figs. 1B and 7D). Both the negative and positive inotropic effects of ET-1 were observed in the presence of 2-APB, although the increase in systolic $\mathrm{Ca}^{2+}$ rise was significantly decreased by the $\mathrm{InsP}_{3} \mathrm{R}$ antagonist. For example, at $12 \mathrm{~min}$ post-ET- 1 addition the systolic $\mathrm{Ca}^{2+}$ rise was $917 \pm 112$. Whereas, in cells stimulated with ET-1 +2APB the systolic $\mathrm{Ca}^{2+}$ transient amplitude was $498 \pm 80 \mathrm{nM}$ $(p<0.05 ; n=5)$. Another effect of 2 -APB was to reduce the incidence of ET-1-evoked SCTs. All cells stimulated with ET1 alone $(n=10)$ or ET- $1+2$-APB $(n=5)$ displayed SCTs, but they were substantially less common if 2-APB was present. Furthermore, no cells $(n=5)$ stimulated with ET- $1+2-\mathrm{APB}$ progressed to the condition where they were inert to the external pacing (Fig. 7D).

\section{Discussion}

ET-1 is known to exert several effects on cardiac function [20]. In the present study, we explored the consequence of prolonged stimulation of atrial myocytes with ET-1, and observed a complex pattern of response that included negative and positive inotropy, and the generation of pro-arrhythmic SCTs (Figs. 1 and 2). The positive inotropy and SCTs appeared concurrently (Fig. 4), and in some myocytes the SCTs became so frequent that they prevented the cells from being regularly paced (Fig. 1B). It was evident that the SCTs could take several different forms, ranging from isolated $\mathrm{Ca}^{2+}$ sparks to full-blown action potentials (Figs. 4-6). In addition, we determined that $\mathrm{InsP}_{3}$ was the major cause of SCTs in ET-1-stimulated cells (Fig. 7).

The inotropic effects of ET-1 correlated with alterations of the spatial profile of systolic $\mathrm{Ca}^{2+}$ signals. During the negative inotropic phase, both the subsarcolemmal and central $\mathrm{Ca}^{2+}$ responses were diminished. The signals underlying the negative inotropic action of ET-1 are not entirely clear. A suggested mechanism is a transient decrease in the current carried by VOCs during EC-coupling [58], possibly due to a reduction in intracellular cAMP or following activation of PKC [59]. The positive inotropic effect of ET-1 has been suggested to be mediated by several mechanisms, as described earlier. In this study, we demonstrated that $\mathrm{InsP}_{3}$ is responsible for a 
(A)

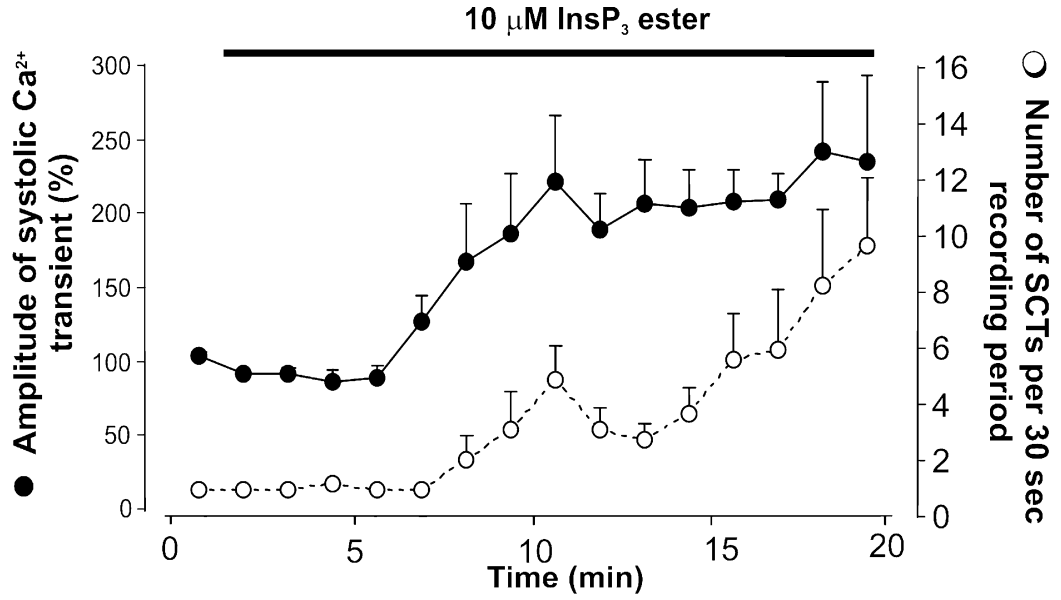

(B)

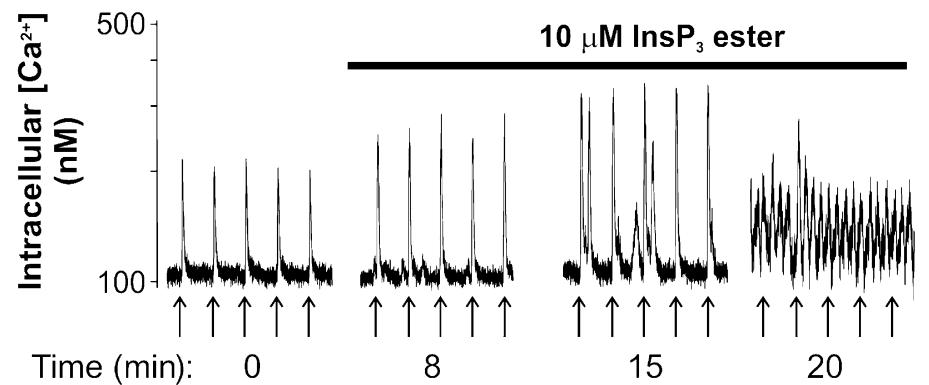

(C)

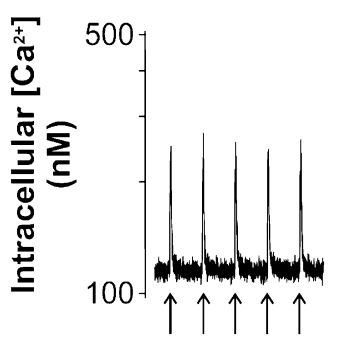

Time $(\min ): 0$

(D)

\section{$2 \mu \mathrm{M} 2-\mathrm{APB}$}

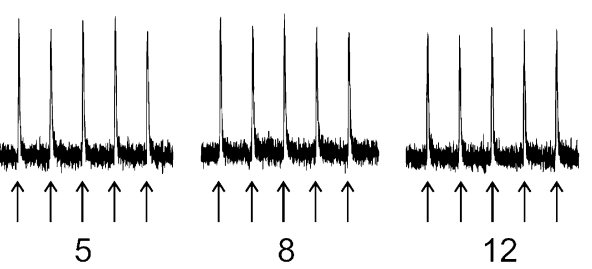

$100 \mathrm{nM} E \mathrm{ET}+2 \mu \mathrm{M} 2-\mathrm{APB}$

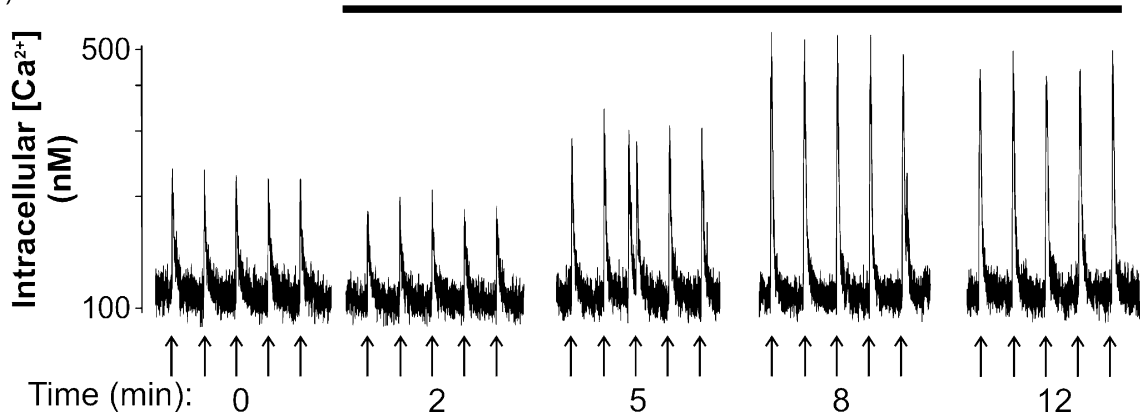

Fig. 7. InsP $\mathrm{P}_{3}$ is a positive inotropic and pro-arrhythmic factor in atrial myocytes, and underlies the SCT-generating action of ET-1. Panel A depicts the effect of continuous stimulation of indo-1-loaded atrial myocytes with $\mathrm{InsP}_{3}$ ester $(10 \mu \mathrm{M})$ on systolic $\mathrm{Ca}^{2+}$ signals and the frequency of SCTs. The data points show the normalised systolic $\mathrm{Ca}^{2+}$ transient amplitude monitored using photometry (data capture rate $2 \mathrm{~ms}$ ). Data were obtained by averaging the peak systolic signal over 30 s periods, and sampling at $90 \mathrm{~s}$ intervals. The SCT frequency was calculated by counting the number of SCTs apparent in the photometry traces during the 30 s intervals when systolic $\mathrm{Ca}^{2+}$ was monitored. The symbols indicate mean \pm S.E.M. $(n=5)$. The photometry traces in panels B-D show representative indo-1 signals from single electrically paced atrial myocytes, and are typical of at least 10 cells from 3 different cell preparations. The vertical arrows indicate

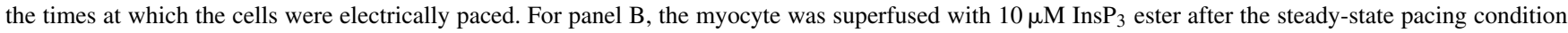
had been established. The response depicted in panel $\mathrm{C}$ was obtained from an atrial myocyte that was superfused with extracellular buffer supplemented with $2 \mu \mathrm{M}$ 2-APB. Panel D shows the response a myocyte to superfusion with $100 \mathrm{nM}$ ET- $1+2 \mu \mathrm{M} 2$-APB. 
portion of the positive inotropic effect of ET-1 (Fig. 7). Direct stimulation of $\mathrm{InsP}_{3} \mathrm{R}$ with the $\mathrm{InsP}_{3}$ ester promoted positive inotropy, whereas antagonism of InsP $\mathrm{P}_{3} \mathrm{Rs}$ during ET-1 stimulation reduced the increase in systolic $\mathrm{Ca}^{2+}$. The most likely way in which $\mathrm{InsP}_{3}$ can act as a positive inotrope is to provide an extra source of $\mathrm{Ca}^{2+}$ during EC-coupling. Although $\mathrm{InsP}_{3} \mathrm{Rs}$ require $\mathrm{InsP}_{3}$ for channel opening, the activation of InsP ${ }_{3} \mathrm{Rs}$ is complex and their open probability is dependent on the ambient $\mathrm{Ca}^{2+}$ concentration. Up to approximately $500 \mathrm{nM}, \mathrm{Ca}^{2+}$ works synergistically with $\mathrm{InsP}_{3}$ to activate $\mathrm{InsP}_{3} \mathrm{Rs}$ [60-63]. InsP $\mathrm{P}_{3} \mathrm{Rs}$ can therefore function as CICR channels. It is plausible that they can sense and respond to the trigger $\mathrm{Ca}^{2+}$ signal that enters through the VOCs at the initiation of EC-coupling, and thereby provide a boost to the systolic $\mathrm{Ca}^{2+}$ transient. A population of $\mathrm{InsP}_{3} \mathrm{Rs}$ has been identified at the subsarcolemmal junctions where the VOCs and RyR are closely opposed [21,33]. In this strategic location, $\mathrm{InsP}_{3} \mathrm{Rs}$ are ideally placed to sysnergise with the other $\mathrm{Ca}^{2+}$ channels and enhance EC-coupling.

The junctional location of InsP $\mathrm{P}_{3}$ Rs could also explain the spatial origin of SCTs. The isolated $\mathrm{Ca}^{2+}$ sparks (Fig. 4), flurries of $\mathrm{Ca}^{2+}$ sparks (both transient flurries and those that triggered action potentials; Fig. 5) and $\mathrm{Ca}^{2+}$ waves (Fig. 6) were all predominantely observed in the subsarcolemmal region. Promiscuous firing of subsarcolemmal $\mathrm{InsP}_{3} \mathrm{Rs}$, and the subsequent recruitment of RyRs by CICR could explain the prevalence of SCTs in the periphery of atrial myocytes.

An unexpected effect of ET-1 stimulation was to modify nuclear $\mathrm{Ca}^{2+}$ concentration differentially from the surrounding cytoplasm (Fig. 3). The secondary surge of $\mathrm{Ca}^{2+}$ within the nucleus depicted in Fig. 3Biii was spatially and temporally distinct from the decreasing $\mathrm{Ca}^{2+}$ levels within the cytoplasm. The topic of autonomous nuclear $\mathrm{Ca}^{2+}$ signalling has a long and controversial literature, with many discrepant findings [64-66]. Whilst we have observed cytosolic $\mathrm{Ca}^{2+}$ signals that had a significant and longer-lasting effect on nucleoplasmic $\mathrm{Ca}^{2+}$ [49], we had not previously found a nuclear $\mathrm{Ca}^{2+}$ signal that appeared to be uncoordinated with the surrounding cytoplasmic $\mathrm{Ca}^{2+}$ concentration. Identifying the source of the $\mathrm{Ca}^{2+}$ underlying the nuclear secondary surge shown in Fig. 3 will require further work. However, it is interesting to note that $\mathrm{InsP}_{3} \mathrm{Rs}$ have been observed in the perinuclear region/nuclear envelope of cardiac myocytes and could therefore be responsible [67].

In summary, ET-1 has a complex mixture of effects on atrial myocyte EC-coupling. The signal transduction cascades engaged by ET-1 are not fully established. However, it appears that $\mathrm{InsP}_{3} \mathrm{Rs}$ are recruited by ET-1 and mediate some of its actions. In particular, positive inotropy and arrhythmogenesis. Consistent with our data, genetic ablation of InsP $\mathrm{P}_{3} \mathrm{R}$ expression in atrial myocytes prevents the positive inotropic and SCT-generating actions of ET-1 [22]. We have observed similar actions of $\mathrm{InsP}_{3}$ on ventricular myocytes [50]. Although due to the lesser expression of InsP $\mathrm{P}_{3} \mathrm{Rs}$ in ventricular cells [33], the effects of $\mathrm{InsP}_{3}$ were not as profound as with atrial myocytes. Given that $\mathrm{InsP}_{3} \mathrm{Rs}$ have a dual nature of increasing physiological signalling (inotropy) and causing pathological signals (SCTs), it is somewhat paradoxical that InsP ${ }_{3}$ Rs would be utilised by cardiac myocytes. The regular activation of cardiomyocytes is critical to not disturb the cardiac cycle. The data presented herein suggest that the modest inotropic effect of $\mathrm{InsP}_{3} \mathrm{Rs}$ comes with a significant ability to disrupt EC-coupling.

\section{Acknowledgements}

This work was supported by the British Heart Foundation (Grant number PG/06/034/20637) and the BBSRC. HLR is a Royal Society University Research Fellow.

\section{References}

[1] D.M. Bers, Cardiac excitation-contraction coupling, Nature 415 (2002) 198-205.

[2] G. Callewaert, Excitation-contraction coupling in mammalian cardiac cells, Cardiovasc. Res. 26 (1992) 923-932.

[3] H.L. Roderick, M.J. Berridge, M.D. Bootman, Calcium-induced calcium release, Curr. Biol. 13 (2003) R425.

[4] H. Cheng, W.J. Lederer, M.B. Cannell, Calcium sparks: elementary events underlying excitation-contraction coupling in heart muscle, Science 262 (1993) 740-744.

[5] M.B. Cannell, H. Cheng, W.J. Lederer, The control of calcium release in heart muscle, Science 268 (1995) 1045-1049.

[6] E. Rios, The $\mathrm{Ca}^{2+}$ spark of mammalian muscle. Physiology or pathology? J. Physiol. 565 (2005) 705.

[7] M.D. Bootman, P. Lipp, M.J. Berridge, The organisation and functions of local $\mathrm{Ca}(2+)$ signals, J. Cell Sci. 114 (2001) 2213-2222.

[8] S. Guatimosim, K. Dilly, L.F. Santana, M. Saleet Jafri, E.A. Sobie, W.J. Lederer, Local $\mathrm{Ca}(2+)$ signaling and $\mathrm{EC}$ coupling in heart: $\mathrm{Ca}(2+)$ sparks and the regulation of the $[\mathrm{Ca}(2+)](\mathrm{i})$ transient, J. Mol. Cell. Cardiol. 34 (2002) 941-950.

[9] M.D. Bootman, D.R. Higazi, S. Coombes, H.L. Roderick, Calcium signalling during excitation-contraction coupling in mammalian atrial myocytes, J. Cell Sci. 119 (2006) 3915-3925.

[10] F. Brette, C. Orchard, T-tubule function in mammalian cardiac myocytes, Circ. Res. 92 (2003) 1182-1192.

[11] S.L. Carl, K. Felix, A.H. Caswell, N.R. Brandt, W.J. Ball Jr., P.L. Vaghy, G. Meissner, D.G. Ferguson, Immunolocalization of sarcolemmal dihydropyridine receptor and sarcoplasmic reticular triadin and ryanodine receptor in rabbit ventricle and atrium, J. Cell Biol. 129 (1995) 672-682.

[12] L. Mackenzie, M.D. Bootman, M.J. Berridge, P. Lipp, Predetermined recruitment of calcium release sites underlies excitation-contraction coupling in rat atrial myocytes, J. Physiol. 530 (2001) 417-429.

[13] J.R. Berlin, Spatiotemporal changes of $\mathrm{Ca}^{2+}$ during electrically evoked contractions in atrial and ventricular cells, Am. J. Physiol. 269 (1995) H1165-H1170.

[14] S.H. Woo, L. Cleemann, M. Morad, $\mathrm{Ca}^{2+}$ current-gated focal and local $\mathrm{Ca}^{2+}$ release in rat atrial myocytes: evidence from rapid 2-D confocal imaging, J. Physiol. 543 (2002) 439-453.

[15] K.A. Sheehan, L.A. Blatter, Regulation of junctional and non-junctional sarcoplasmic reticulum calcium release in excitation-contraction coupling in cat atrial myocytes, J. Physiol. 546 (2003) 119-135.

[16] Y. Chen-Izu, S.L. McCulle, C.W. Ward, C. Soeller, B.M. Allen, C. Rabang, M.B. Cannell, C.W. Balke, L.T. Izu, Three-dimensional distribution of ryanodine receptor clusters in cardiac myocytes, Biophys. J. 91 (2006) 1-13. 
[17] L. Mackenzie, H.L. Roderick, M.J. Berridge, S.J. Conway, M.D. Bootman, The spatial pattern of atrial cardiomyocyte calcium signalling modulates contraction, J. Cell Sci. 117 (2004) 6327-6337.

[18] O. Zolk, F. Munzel, T. Eschenhagen, Effects of chronic endothelin-1 stimulation on cardiac myocyte contractile function, Am. J. Physiol. Heart Circ. Physiol. 286 (2004) H1248-H1257.

[19] F. Duru, M. Barton, T.F. Luscher, R. Candinas, Endothelin and cardiac arrhythmias: do endothelin antagonists have a therapeutic potential as antiarrhythmic drugs? Cardiovasc. Res. 49 (2001) 272-280.

[20] F.D. Russell, P. Molenaar, The human heart endothelin system: ET-1 synthesis, storage, release and effect, Trends Pharmacol. Sci. 21 (2000) 353-359.

[21] L. Mackenzie, M.D. Bootman, M. Laine, M.J. Berridge, J. Thuring, A. Holmes, W.H. Li, P. Lipp, The role of inositol 1,4,5-trisphosphate receptors in $\mathrm{Ca}(2+)$ signalling and the generation of arrhythmias in rat atrial myocytes, J. Physiol. 541 (2002) 395-409.

[22] X. Li, A.V.Zima, F. Sheikh, L.A. Blatter, J. Chen, Endothelin-1-induced arrhythmogenic $\mathrm{Ca}^{2+}$ signaling is abolished in atrial myocytes of inositol-1,4,5-trisphosphate(IP3)-receptor type 2-deficient mice, Circ. Res. 96 (2005) 1274-1281.

[23] J.Q. He, Y. Pi, J.W. Walker, T.J. Kamp, Endothelin-1 and photoreleased diacylglycerol increase L-type $\mathrm{Ca}^{2+}$ current by activation of protein kinase C in rat ventricular myocytes, J. Physiol. 524 (Pt 3) (2000) 807-820.

[24] G.O. Andersen, E. Qvigstad, I. Schiander, H. Aass, J.B. Osnes, T. Skomedal, Alpha(1)-AR-induced positive inotropic response in heart is dependent on myosin light chain phosphorylation, Am. J. Physiol. Heart Circ. Physiol. 283 (2002) H1471-H1480.

[25] Y. Pi, D. Zhang, K.R. Kemnitz, H. Wang, J.W. Walker, Protein kinase $\mathrm{C}$ and A sites on troponin I regulate myofilament $\mathrm{Ca}^{2+}$ sensitivity and ATPase activity in the mouse myocardium, J. Physiol. 552 (2003) $845-857$.

[26] L. Chu, I. Norota, M. Endoh, Differential inhibition by the Rho kinase inhibitor Y-27632 of the increases in contractility and $\mathrm{Ca}^{2+}$ transients induced by endothelin-1 in rabbit ventricular myocytes, Naunyn Schmiedebergs Arch. Pharmacol. 371 (2005) 185-194.

[27] M.J. Berridge, M.D. Bootman, H.L. Roderick, Calcium signalling: dynamics, homeostasis and remodelling, Nat. Rev. Mol. Cell Biol. 4 (2003) 517-529.

[28] H.L. Roderick, M.D. Bootman, Bi-directional signalling from the InsP3 receptor: regulation by calcium and accessory factors, Biochem. Soc. Trans. 31 (2003) 950-953.

[29] C.W. Taylor, P.C. da Fonseca, E. Morris, IP(3) receptors: the search for structure, Trends Biochem. Sci. 29 (2004) 210-219.

[30] J.K. Foskett, C. White, K.H. Cheung, D.O. Mak, Inositol trisphosphate receptor $\mathrm{Ca}^{2+}$ release channels, Physiol. Rev. 87 (2007) 593-658.

[31] S.A. Walker, P.J. Cullen, J.A. Taylor, P.J. Lockyer, Control of Ras cycling by $\mathrm{Ca}^{2+}$, FEBS Lett. 546 (2003) 6-10.

[32] G.M. Springett, H. Kawasaki, D.R. Spriggs, Non-kinase secondmessenger signaling: new pathways with new promise, Bioessays 26 (2004) 730-738.

[33] P. Lipp, M. Laine, S.C. Tovey, K.M. Burrell, M.J. Berridge, W. Li, M.D. Bootman, Functional InsP3 receptors that may modulate excitation-contraction coupling in the heart, Curr. Biol. 10 (2000) 939-942.

[34] J. Yamada, T. Ohkusa, T. Nao, T. Ueyama, M. Yano, S. Kobayashi, K. Hamano, K. Esato, M. Matsuzaki, Up-regulation of inositol 1,4,5 trisphosphate receptor expression in atrial tissue in patients with chronic atrial fibrillation, J. Am. Coll. Cardiol. 37 (2001) 1111-1119.

[35] L. Lencesova, K. Ondrias, L. Micutkova, M. Filipenko, R. Kvetnansky, O. Krizanova, Immobilization stress elevates IP(3) receptor mRNA in adult rat hearts in a glucocorticoid-dependent manner, FEBS Lett. 531 (2002) 432-436.

[36] D.J. Bare, C.S. Kettlun, M. Liang, D.M. Bers, G.A. Mignery, Cardiac type 2 inositol 1,4,5-trisphosphate receptor: interaction and modulation by calcium/calmodulin-dependent protein kinase II, J. Biol. Chem. 280 (2005) 15912-15920.
[37] P.J. Perez, J. Ramos-Franco, M. Fill, G.A. Mignery, Identification and functional reconstitution of the type 2 inositol 1,4,5-trisphosphate receptor from ventricular cardiac myocytes, J. Biol. Chem. 272 (1997) 23961-23969.

[38] T.P. Remus, A.V. Zima, J. Bossuyt, D.J. Bare, J.L. Martin, L.A Blatter, D.M. Bers, G.A. Mignery, Biosensors to measure inositol 1,4,5-trisphosphate concentration in living cells with spatiotemporal resolution, J. Biol. Chem. 281 (2006) 608-616.

[39] T.M. Nosek, M.F. Williams, S.T. Zeigler, R.E. Godt, Inositol trisphosphate enhances calcium release in skinned cardiac and skeletal muscle, Am. J. Physiol. 250 (1986) C807-C811.

[40] J.C. Gilbert, T. Shirayama, A.J. Pappano, Inositol trisphosphate promotes $\mathrm{Na}-\mathrm{Ca}$ exchange current by releasing calcium from sarcoplasmic reticulum in cardiac myocytes, Circ. Res. 69 (1991) 1632-1639.

[41] B. Felzen, M. Shilkrut, H. Less, I. Sarapov, G. Maor, R. Coleman, R.B. Robinson, G. Berke, O. Binah, Fas (CD95/Apo-1)-mediated damage to ventricular myocytes induced by cytotoxic $\mathrm{T}$ lymphocytes from perforin-deficient mice: a major role for inositol 1,4,5-trisphosphate, Circ. Res. 82 (1998) 438-450.

[42] L. Mackenzie, H.L. Roderick, A. Proven, S.J. Conway, M.D. Bootman, Inositol 1,4,5-trisphosphate receptors in the heart, Biol. Res. 37 (2004) $553-557$.

[43] A.V. Zima, L.A. Blatter, Inositol-1,4,5-trisphosphate-dependent $\mathrm{Ca}(2+)$ signalling in cat atrial excitation-contraction coupling and arrhythmias, J. Physiol. 555 (2004) 607-615.

[44] X. Wu, T. Zhang, J. Bossuyt, X. Li, T.A. McKinsey, J.R. Dedman, E.N. Olson, J. Chen, J.H. Brown, D.M. Bers, Local InsP3-dependent perinuclear $\mathrm{Ca}^{2+}$ signaling in cardiac myocyte excitation-transcription coupling, J. Clin. Invest. 116 (2006) 675-682.

[45] L.O. Go, M.C. Moschella, J. Watras, K.K. Handa, B.S. Fyfe, A.R. Marks, Differential regulation of two types of intracellular calcium release channels during end-stage heart failure, J. Clin. Invest. 95 (1995) 888-894.

[46] E.A. Woodcock, S.J. Matkovich, Ins(1,4,5)P3 receptors and inositol phosphates in the heart-evolutionary artefacts or active signal transducers? Pharmacol. Ther. 107 (2005) 240-251.

[47] G. Callewaert, P. Lipp, L. Pott, E. Carmeliet, High-resolution measurement and calibration of $\mathrm{Ca}(2+)$-transients using Indo-1 in guinea-pig atrial myocytes under voltage clamp, Cell Calcium 12 (1991) 269-277.

[48] M.C. Capogrossi, M.D. Stern, H.A. Spurgeon, E.G. Lakatta, Spontaneous $\mathrm{Ca}^{2+}$ release from the sarcoplasmic reticulum limits $\mathrm{Ca}^{2+}$-dependent twitch potentiation in individual cardiac myocytes. A mechanism for maximum inotropy in the myocardium, J. Gen. Physiol. 91 (1988) 133-155.

[49] P. Lipp, D. Thomas, M.J. Berridge, M.D. Bootman, Nuclear calcium signalling by individual cytoplasmic calcium puffs, EMBO J. 16 (1997) 7166-7173.

[50] A. Proven, H.L. Roderick, S.J. Conway, M.J. Berridge, J.K. Horton, S.J. Capper, M.D. Bootman, Inositol 1,4,5-trisphosphate supports the arrhythmogenic action of endothelin- 1 on ventricular cardiac myocytes, J. Cell Sci. 119 (2006) 3363-3375.

[51] S.C. Tovey, P. de Smet, P. Lipp, D. Thomas, K.W. Young, L. Missiaen, H. De Smedt, J.B. Parys, M.J. Berridge, J. Thuring, A. Holmes, M.D. Bootman, Calcium puffs are generic InsP(3)-activated elementary calcium signals and are downregulated by prolonged hormonal stimulation to inhibit cellular calcium responses, J. Cell Sci. 114 (2001) 3979-3989.

[52] F.W. Johenning, M. Zochowski, S.J. Conway, A.B. Holmes, P. Koulen, B.E. Ehrlich, Distinct intracellular calcium transients in neurites and somata integrate neuronal signals, J. Neurosci. 22 (2002) 5344 5353.

[53] C.M. Peppiatt, T.J. Collins, L. Mackenzie, S.J. Conway, A.B. Holmes, M.D. Bootman, M.J. Berridge, J.T. Seo, H.L. Roderick, 2-Aminoethoxydiphenyl borate (2-APB) antagonises inositol 1,4,5trisphosphate-induced calcium release, inhibits calcium pumps and has a use-dependent and slowly reversible action on store-operated calcium entry channels, Cell Calcium 34 (2003) 97-108. 
[54] S.C. Tovey, T.A. Goraya, C.W. Taylor, Parathyroid hormone increases the sensitivity of inositol trisphosphate receptors by a mechanism that is independent of cyclic AMP, Br. J. Pharmacol. 138 (2003) 81-90.

[55] E. Vermassen, K. Van Acker, W.G. Annaert, B. Himpens, G. Callewaert, L. Missiaen, H. De Smedt, J.B. Parys, Microtubule-dependent redistribution of the type-1 inositol 1,4,5-trisphosphate receptor in A7r5 smooth muscle cells, J. Cell Sci. 116 (2003) 1269-1277.

[56] R. Chen, I. Valencia, F. Zhong, K.S. McColl, H.L. Roderick, M.D. Bootman, M.J. Berridge, S.J. Conway, A.B. Holmes, G.A. Mignery, P. Velez, C.W. Distelhorst, Bcl-2 functionally interacts with inositol 1,4,5-trisphosphate receptors to regulate calcium release from the ER in response to inositol 1,4,5-trisphosphate, J. Cell Biol. 166 (2004) 193-203

[57] N.N. Kasri, A.M. Holmes, G. Bultynck, J.B. Parys, M.D. Bootman, K. Rietdorf, L. Missiaen, F. McDonald, H. De Smedt, S.J. Conway, A.B. Holmes, M.J. Berridge, H.L. Roderick, Regulation of InsP3 receptor activity by neuronal $\mathrm{Ca}^{2+}$-binding proteins, EMBO J. 23 (2004) 312-321.

[58] S.H. Woo, C.O. Lee, Effects of endothelin-1 on $\mathrm{Ca}^{2+}$ signaling in guinea-pig ventricular myocytes: role of protein kinase C, J. Mol. Cell. Cardiol. 31 (1999) 631-643.

[59] M. Izumi, S. Miyamoto, M. Hori, H. Ozaki, H. Karaki, Negative inotropic effect of endothelin-1 in the mouse right ventricle, Eur. J. Pharmacol. 396 (2000) 109-117.
[60] M. Iino, Biphasic $\mathrm{Ca}^{2+}$ dependence of inositol 1,4,5-trisphosphateinduced $\mathrm{Ca}$ release in smooth muscle cells of the guinea pig taenia caeci, J. Gen. Physiol. 95 (1990) 1103-1122.

[61] I. Bezprozvanny, J. Watras, B.E. Ehrlich, Bell-shaped calcium-response curves of Ins(1,4,5)P3- and calcium-gated channels from endoplasmic reticulum of cerebellum, Nature 351 (1991) 751-754.

[62] L. Missiaen, H. De Smedt, J.B. Parys, R. Casteels, Co-activation of inositol trisphosphate-induced $\mathrm{Ca}^{2+}$ release by cytosolic $\mathrm{Ca}^{2+}$ is loading-dependent, J. Biol. Chem. 269 (1994) 7238-7242.

[63] M.D. Bootman, L. Missiaen, J.B. Parys, H. De Smedt, R. Casteels, Control of inositol 1,4,5-trisphosphate-induced $\mathrm{Ca}^{2+}$ release by cytosolic $\mathrm{Ca}^{2+}$, Biochem. J. 306 (Pt 2) (1995) 445-451.

[64] M.D. Bootman, D. Thomas, S.C. Tovey, M.J. Berridge, P. Lipp, Nuclear calcium signalling, Cell. Mol. Life. Sci. 57 (2000) 371-378.

[65] M.F. Leite, E.C. Thrower, W. Echevarria, P. Koulen, K. Hirata, A.M. Bennett, B.E. Ehrlich, M.H. Nathanson, Nuclear and cytosolic calcium are regulated independently, Proc. Natl. Acad. Sci. U.S.A. 100 (2003) 2975-2980

[66] O. Gerasimenko, J. Gerasimenko, New aspects of nuclear calcium signalling, J. Cell Sci. 117 (2004) 3087-3094

[67] D.J. Bare, D.M. Bars, G.A. Mignery, InsP(3) receptors in ventricular myocytes are primarily in the nuclear envelope, associate with CaMKII delta, and are phosphorylation targets, Circulation 110 (2004) 159_ 160 